\title{
Photo-Induced Surface Reaction of Highly Oriented Anatase Polycrystalline Films Synthesized Using a CVD Apparatus Operated in Atmospheric Regime
}

\author{
Shuji TOKITA, ${ }^{* *}$ Norio TANAKA, ${ }^{*}$ Shigeo OHSHIO** and Hidetoshi SAITOH** \\ Tokita CVD Systems Co., Ltd., 30-26, Hinode-cho, Yoshida-machi, Nishikanbara-gun, Niigata 959-0231 \\ *Environmental Science Research Niigata, 8-13, Higashisakae-cho, Yoshida-machi, Nishikanbara-gun, Niigata $959-0291$ \\ **Department of Chemistry, Nagaoka University of Technology, 1603-1, Kamitomioka-cho, Nagaoka-shi, Niigata 940-2188
}

\section{大気開放型化学気相析出装置により作製された高配向アナターゼ多結晶膜の光誘起表面反応 時田修二** · 田中教雄* $\cdot$ 大塩茂夫** ·斎藤秀俊** \\ 時田シーブイディーシステムズ(株), 959-0231 新潟県西蒲原郡吉田町日之出町 30-26 \\ *新潟県環境衛生研究所, 959-0291 新潟県西蒲原町吉田町東栄町 8-13 \\ **長岡技術科学大学化学系, 940-2188 新潟県長岡市上富岡町 1603-1}

\begin{abstract}
High-rate growth of polycrystalline anatase films was achieved on non-epitaxial substrates using a chemicalvapor-deposition technique operated under air atmosphere. As the growth rate of each crystalline face was strongly dependent on the deposition conditions, four types of anatase polycrystalline films were fabricated with several oriented directions such as $\langle 112\rangle,\langle 110\rangle,\langle 100\rangle$ and $\langle 001\rangle$. The photo-induced surface reaction of the anatase films was evaluated by the reduction ability of methylene blue under ultraviolet irradiation by an ultraviolet fluorescent lamp. The reduction rate of methylene blue was found to be affected by the preferential growth direction of crystallites.

[Received November 5, 2002; Accepted March 24, 2003]
\end{abstract}

Key-words : Anatase, Film, CVD, Photo-induced reaction, Orientation, SEM, XRD

\section{Introduction}

Anatase films with various preferential growth directions were deposited on silicon substrates using an atmospheric chemical-vapor-deposition (CVD) apparatus. ${ }^{1), 2)}$ Atmospheric CVD is an air-opened film formation route for creating highly oriented metal-oxide films through the use of solid and liquid complexes. Film growth is achieved without the need for a vacuum chamber, which reduces the difficulty of operation and eliminates the need for an ultrahigh vacuum. In addition, high-rate growth of metal oxide films is easily achieved using this technique. ${ }^{3)}$-7) For example, the anatase film consisting of $\langle 001\rangle$-oriented columnar crystals grows at a deposition rate of $4 \mathrm{~nm} / \mathrm{s}$. $\langle 100\rangle$ - and $\langle 211\rangle$ oriented crystallites grow at a relatively high rate, $45 \mathrm{~nm} / \mathrm{s}$.

It is widely known that the photosemiconducting property of titania crystallites introduces photo-induced reaction on the surface. ${ }^{8)}$ Photon energy absorption induces hole-electron pair generation on the surface of intrinsic semiconductors. Anatase absorbs the ultraviolet ray having a photon energy $>3.2 \mathrm{eV}$. In aqueous solution, the hole combines with the slightly dissociated hydrogen ion, resulting in the formation of a hydroxyl group on the anatase surface. Therefore, the hydroxyl group replaces the termination structure. ${ }^{9)}$

$$
-\mathrm{O}-\mathrm{Ti}^{+}+\mathrm{OH}^{-} \longrightarrow-\mathrm{O}-\mathrm{Ti}-\mathrm{OH}
$$

Methylene blue is a bright blue water-soluble dye that is stable in air-saturated solution upon irradiation at wavelengths longer than $300 \mathrm{~nm}$, but is completely photo-oxidatively degraded by irradiation in this same wavelength region in the presence of $\mathrm{TiO}_{2} .{ }^{10}$ )

As for the surface reaction, we expect that the ability of the photocatalytic property of anatase is decided by the atomic order configuration of the crystallite surface due to the difference of surface energy. ${ }^{11}$ Therefore, crystallographic growth direction of the film should become one of the important parameter to decide the photocatalytic property of the deposited film. In this note, the relationship between the preferential orientation and the photocatalytic ability of the anatase polycrystalline films will be described and discussed.

\section{Experimental}

For polycrystalline film growth, a quartz glass sheet was prepared in this experiment. The quartz glass sheet was cut into $10 \times 10 \times 1 \mathrm{~mm}^{3}$. The anatase films were fabricated on the substrate using the atmospheric CVD apparatus previously used to synthesize anatase polycrystalline films. ${ }^{1)}$ As the reactant, titanium tetra-isopropoxide, $\mathrm{Ti}\left(\mathrm{O}-i-\mathrm{C}_{3} \mathrm{H}_{7}\right)_{4}$ (Nacalai Tesque, Inc., quoted purity of $99.9 \%$ ) was selected. The reactant was loaded in a vaporizer and vaporized in the range from 70 to $150^{\circ} \mathrm{C}$. The reactant vapor was carried by nitrogen gas and sprayed from the nozzle onto the substrate. The flow rate of carrier gas was kept constant at 1.5 $l /$ min. The distance between the nozzle and the substrate was kept at $20 \mathrm{~mm}$. The deposition duration was maintained between 20 and $600 \mathrm{~s}$ to form $1-\mu \mathrm{m}$-thick film. The substrate was heated by an electric heater placed behind the substrate. The substrate temperature was varied in the range from 450 to $500^{\circ} \mathrm{C}$. In particular, the vaporizing temperature is the most important parameter to vary crystalline orientation.

Microstructural characterizations, such as the determination of the thickness and the crystallite size of the film, were performed with scanning electron spectroscopy (SEM; JSM T-300, JEOL Ltd.). The growth rate was calculated from the thickness of deposited film. The surface area of the polycrystalline films was also analyzed using the results of the SEM surface and cross-sectional observations. Phase identification and crystallographic orientation of the sample were determined by an X-ray diffraction (XRD; MXP-3, MAC Science Co.) technique using $\theta-2 \theta$ scans.

For the evaluation of the ability of the photo-induced surface reaction, $1 \mathrm{mmol} / 1$ methylene blue aqueous solution was dropped in a glass cell $10 \times 10 \times 1 \mathrm{~mm}^{3}$ in size; then the cell was sealed. There was a $25 \mu \mathrm{m}$ spacer having a window 
of $8 \mathrm{~mm}$ in diameter, resulting in a volume of $1.25 \mathrm{~mm}^{3}$ of methylene blue solution. A $352 \mathrm{~nm}$ ultraviolet ray was introduced into the cell placed $30 \mathrm{~mm}$ from an ultraviolet source with energy of $1 \mathrm{~mW} / \mathrm{cm}^{2}$. The concentration of solution was examined using a color-difference meter (CM-2002, Minolta Co.). A difference of absorbance, $\triangle \mathrm{ABS}$, was calculated from the logarithm of the ratio of absorbance at $580 \mathrm{~nm}$ in wavelength on the initial stage to that on each time.

\section{Result and discussion}

Figure 1 shows the $\theta-2 \theta$ XRD pattern obtained from the films deposited on the quartz glass substrate. All these films deposited on the quartz glass substrate had anatase structure having the typical diffraction line at $25.3^{\circ}$ corresponding to (101) diffraction peak. The preferentially $\langle 110\rangle$, $\langle 100\rangle,\langle 001\rangle$ and $\langle 112\rangle$-oriented samples indicated relatively strong $(220),(200),(004)$ and (112) peaks, respectively. The relative intensities of these peaks are stronger than that reported by the International Center for Diffraction Data (card number 21-1272).

The growth rate of the films varied with the growth orientation: $32 \mathrm{~nm} / \mathrm{s}$ for $\langle 110\rangle, 25 \mathrm{~nm} / \mathrm{s}$ for $\langle 100\rangle, 2 \mathrm{~nm} / \mathrm{s}$ for $\langle 001\rangle$ and $4 \mathrm{~nm} / \mathrm{s}$ for $\langle 112\rangle$ directions. These are 100-500 times larger than those obtained using the conventional CVD techniques operated under low pressure. The present technique is thought to be excellent due to the variability of the orientation of anatase films under high-rate growth conditions.

Typical SEM top views of the polycrystalline anatase films are shown in Fig. 2. To obtain a constant thickness of

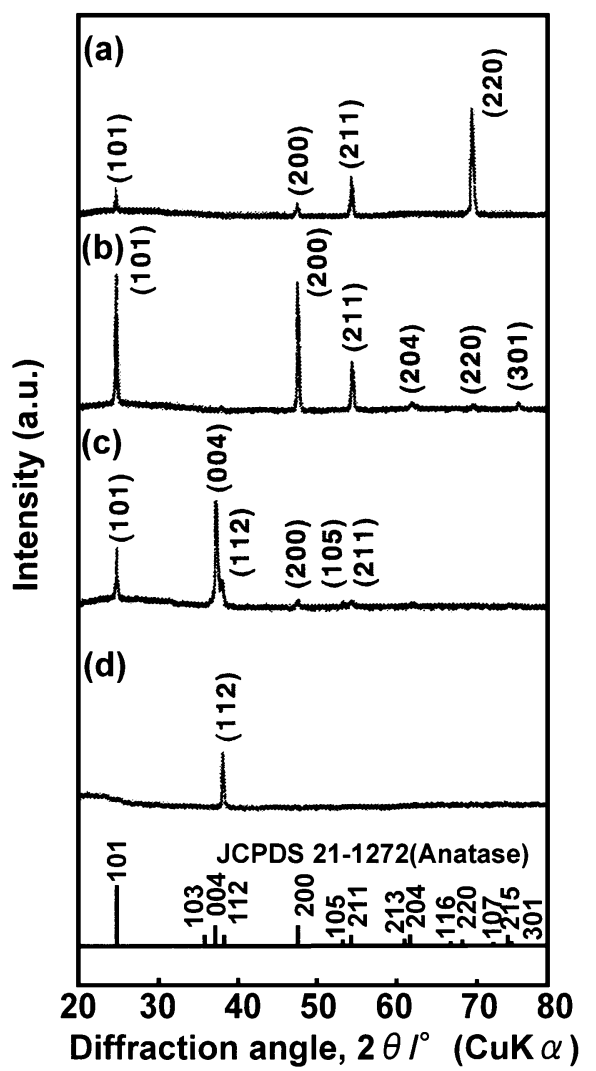

Fig. 1. X-ray diffraction patterns of anatase films with preferential orientations: (a) $\langle 110\rangle$, (b) $\langle 100\rangle$, (c) $\langle 001\rangle$ and (d) $\langle 112\rangle$. Substrate and vaporizing temperatures are (a) $130^{\circ} \mathrm{C}, 500^{\circ} \mathrm{C}$, (b) $100^{\circ} \mathrm{C}, 500^{\circ} \mathrm{C}$, (c) $70^{\circ} \mathrm{C}, 450^{\circ} \mathrm{C}$ and (d) $80^{\circ} \mathrm{C}, 450^{\circ} \mathrm{C}$.
$1 \mu \mathrm{m}$, growth conditions were varied for each orientation. The SEM images were divided into two types: $\langle 100\rangle$ - and $\langle 001\rangle$-oriented samples without clear cavity image on the surface, and $\langle 112\rangle$ - and $\langle 110\rangle$-oriented samples with presence of clear cavities. When the area of an atomically flat surface is defined as 1 , the normalized surface area of the $\langle 110\rangle$-, $\langle 100\rangle$-, $\langle 001\rangle$ - and $\langle 112\rangle$-oriented films is determined as values of $1.9,1.6,2.7$ and 2.2 , respectively. The number density of titanium and oxide ions on each crystalline surface is listed in Table 1.

The reduction rate of methylene blue for each crystallographic orientation was measured using visible ray absorbance of methylene blue solution. The variation of $\triangle \mathrm{ABS}$ is indicated in Fig. 3. Among the samples, the reduction rate obtained from the $\langle 112\rangle$-oriented film is extremely high. Rapid disappearance of the blue color was already achieved at initial stage of ultraviolet ray irradiation to this sample. The reduction rate decreased in the order of $\langle 112\rangle,\langle 110\rangle$,

(a)

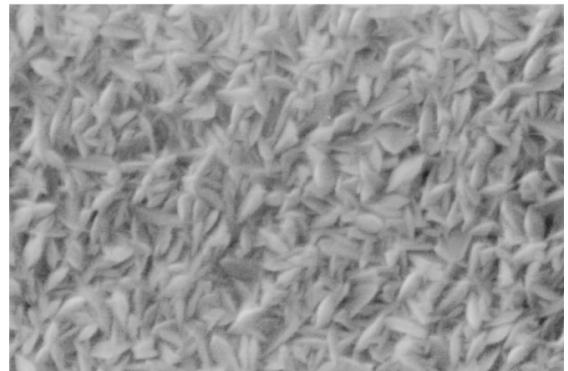

(b)

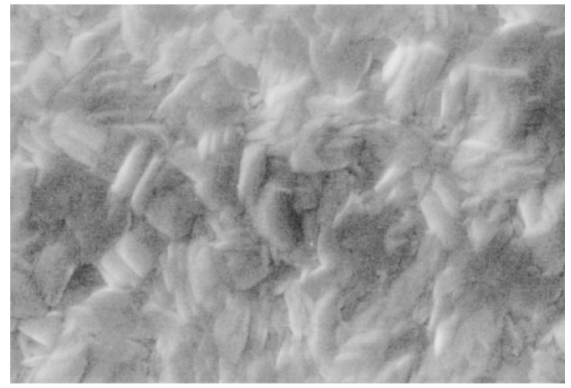

(c)

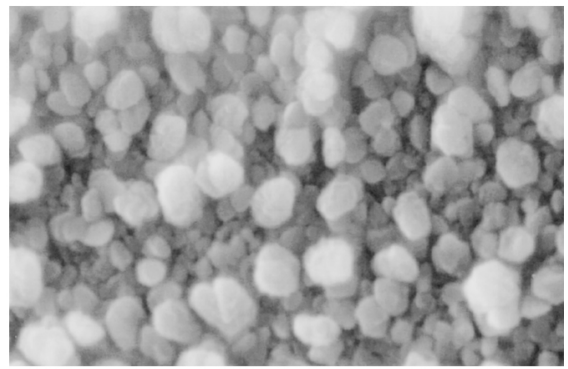

(d)

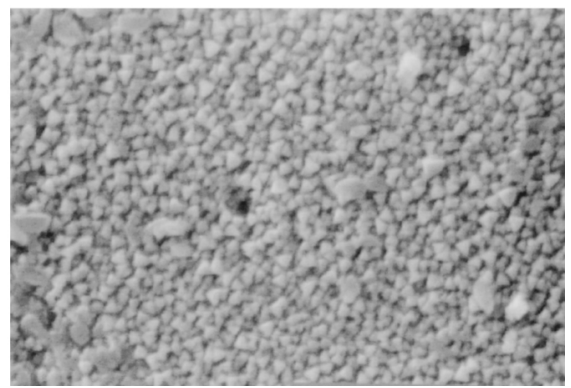

Fig. 2. SEM micrographs of anatase films with preferential orientations: (a) $\langle 110\rangle$, (b) $\langle 100\rangle$, (c) $\langle 001\rangle$ and (d) $\langle 112\rangle$. 
Table 1. Number Density of Ions on the Various Surfaces

\begin{tabular}{ccc}
\hline $\begin{array}{c}\text { Face } \\
\text { index }\end{array}$ & $\begin{array}{c}\mathrm{Ti} \\
\mathrm{x} 10^{14} \mathrm{~cm}^{-2}\end{array}$ & $\begin{array}{c}\mathrm{O} \\
\mathrm{x} 10^{14} \mathrm{~cm}^{-2}\end{array}$ \\
\hline$(001)$ & 6.9 & 14.0 \\
$(110)$ & 5.6 & 11.2 \\
$(110)$ & 3.9 & 5.9 \\
$(112)$ & 9.1 & 13.7 \\
\hline
\end{tabular}

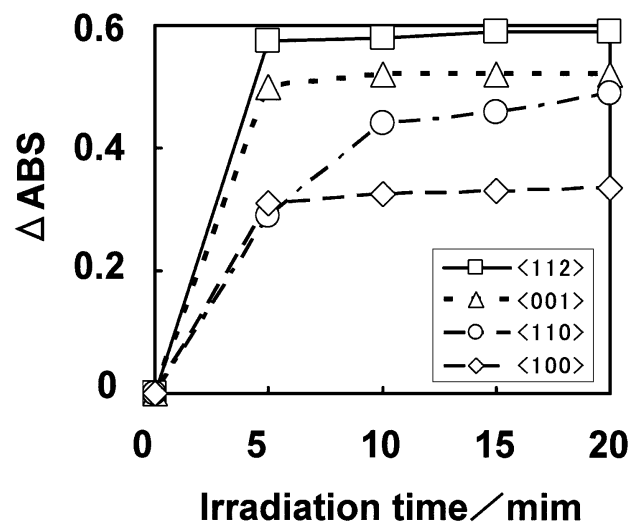

Fig. 3. Reduction characteristics of methylene blue of preferentially oriented polycrystalline anatase film.

$\langle 001\rangle$ and $\langle 100\rangle$. This implies that the growth direction of the anatase crystals is available to be one of the important parameters in optimizing the photo-induced surface reaction of the anatase polycrystalline film. These result also indicate the saturation of $\triangle \mathrm{ABS}$ after $5 \mathrm{~min}$. This saturation is explained as that the rapid reaction occurs at the initial stage of the reaction. Therefore, the absorbance is exponentially decreased during first $5 \mathrm{~min}$.

The structure of anatase formed an accumulation of two unit cells of rock-salt structure with a little distortion in the direction of $c$ axis. The half of the positive ions existing in rock-salt structure is substituted hole. The shade ion is displaced in the direction of $c$ axis. Although the close packing face of the face centered cubic structure is the (111) face, the (112) face of anatase structure is thought to be the closed packing face. This implies that the number density of the active site for the surface reaction is relatively high. Therefore, surface energy is thought to be high.9) Byun et al. fabricated anatase thin film using a vertical low-pressure CVD reactor. The benzene dissociation rate reached a maximum value when the degree of the $\langle 112\rangle$ preferential orientation was increased. ${ }^{12)}$ Here we have to note that the surface energy is a one of the possible reasons to solve the relationship between the surface reaction and the crystallographic orientation of the anatase crystals. On our study and study by Byun et al., the surface index of the growth front $\langle 112\rangle$-oriented anatase crystal is still unknown. The perfect flat surface and defect free crystal are required to discuss scientifically. We are in progress to fabricate well-ordered anatase crystal and evaluate low-temperature photo- and cathodoluminescence.

\section{Conclusion}

Polycrystalline anatase films with various crystallographic orientations were synthesized using the atmospheric CVD apparatus. Anatase films grew oriented to $\langle 110\rangle,\langle 100\rangle$, $\langle 112\rangle$ and $\langle 001\rangle$ with relativity high growth rates. The reduction rate of methylene blue obtained from the $\langle 112\rangle$ oriented film is extremely high.

Acknowledgment This work was supported by the Grant-inAid for Scientific Research (B) from the Ministry of Education, Culture, Sports, Science and Technology under Contract No. 14350350 and 21st COE program at Nagaoka University of Technology.

\section{References}

1) Tanaka, N., Ohshio, S. and Saitoh, H., J. Ceram. Soc. Japan, Vol. 105, pp. 551-555 (1997).

2) Saitoh, H., Sunayama, H., Tanaka, N. and Ohshio, S., J. Ceram. Soc. Japan, Vol. 106, pp. 1051-1055 (1998).

3) Satoh, M., Tanaka, N., Ueda, Y., Ohshio, S. and Saitoh, H., Jpn. J. Appl. Phys., Vol. 38, pp. L586-L589 (1999).

4) Saitoh, H., Satoh, M., Tanaka, N., Ueda, Y. and Ohshio, S., Jpn. J. Appl. Phys., Vol. 38, pp. 6873-6877 (1999).

5) Saitoh, H., Namioka, Y., Sugata, H. and Ohshio, S., Jpn. J. Appl. Phys., Vol. 40, pp. 6024-6028 (2001).

6) Saitoh, Y., Oshio, S. and Saitoh, H., Jpn. J. Appl. Phys., Vol. 41, pp. L1253-L1255 (2002).

7) Saitoh, H., Okada, Y. and Ohshio, S., J. Mater. Sci., Vol. 37, pp. 4597-4602 (2002).

8) Sopyan, I., Watanabe, M., Murasaka, S., Hashimoto, K. and Fujishima, A., Chem. Lett., Vol. 1996, pp. 69-70 (1996).

9) Naskar, S., Pillay, S. A. and Chanda, M., J. Photochem. Photobiol. A: Chem., Vol. 113, pp. 257-264 (1998).

10) Osora, H., Otero, W., Li, L. and Fox, M. A., J. Photchem. Photobiol. B: Biology, Vol. 43, pp. 232-238 (1998).

11) Penn, R. L. and Banfield, J. F., Geochimica et Cosmochimica Acta, Vol. 63, pp. 1549-1557 (1999).

12) Byun, D., Jin, Y., Kim, B., Lee, J. K. and Park, D., J. Hazardous Mater., Vol. 73, pp. 199-206 (2000). 